\title{
The Bulletin of Legal Medicine
}

\author{
Adli Tıp Bülteni
}

\section{RESEARCH ARTICLE}

\section{The Effect of Psychiatric Consultations on Forensic Reports Process}

\author{
Orhan Meral*, Nusret Ayaz
}

\begin{abstract}
:
Objective: In this study, it was aimed to draw attention to the importance of the effect on a forensic report of trauma-related mental health effects and their frequency revealed in psychiatric consultation requested by the Forensic Medicine Polyclinic for cases exposed to different kinds of trauma.

Methods: A retrospective examination was made of 192 cases data consulted to the Psychiatry Department for a report requested by the judicial authorities between June 2016 and September 2019. Psychiatric evaluation of the cases was made by psychiatrists according to the Diagnostic and Statistical Manual of Mental Disorders-5 (DSM-5).

Results: In the study, 192 cases, 54 male $(28.1 \%)$ and 138 female (71.9\%) were evaluated. The average age of the cases was $39.44 \pm 13.84$ years. In $164(85.4 \%)$ cases, the diagnostic criteria of a psychiatric disorder according to DSM-5 were met. Of 164 cases with a psychiatric disorder, although the physical effects of the trauma in 147 (89.6\%) cases were classified as "of a nature which can be eliminated with a simple medical intervention", the injuries of the mental effects were determined as "of a nature which cannot be eliminated with a simple medical intervention". When the relationship between the incident and gender was examined, $76.6 \%$ (n:118) of assault crimes were determined to have been perpetrated against females $(\mathrm{p}<0.005)$.
\end{abstract}

Conclusion: In this study, findings of mental trauma were revealed, and consequently, the effect on the forensic report was determined. A multidisciplinary approach to trauma cases will provide more robust judicial management.

Keywords: Trauma, Forensic Report, Psychiatry, Consultation

Öz:

Amaç: Bu çalışmada, farklı türden travmaya maruz kalmış olgulara Adli Tıp polikliniği tarafindan istenen Psikiyatri konsültasyonun, olgularda travmaya bağlı ruhsal etkilenmenin varlığı ve sıklığının ortaya koyulması ile adli rapor üzerindeki etkisinin önemine dikkat çekilmesi amaçlanmıştır.

Gereç ve Yöntem: Haziran 2016 - Eylül 2019 tarihleri arasında adli rapor için gönderilen olgular arasından Psikiyatri bölümüne konsülte edilen 192 olguya ait veriler retrospektif olarak incelenmiştir. Olguların psikiyatrik değerlendirmesi psikiyatri uzmanları tarafından DSM-5'e (Diagnostic and Statistical Manual of Mental Disorders-5) göre yapılmıştır.

Bulgular: Çalışmada 54'ü (\%28,1) erkek, 138'i (\%71,9) kadın olmak üzere 192 olgu değerlendirilmiştir. Olguların yaş ortalaması 39,44 $( \pm 13,84)$ olarak bulunmuştur. $164(\% 85,4)$ olguda DSM-5'e göre bir psikiyatrik bozukluğu karşılayan tanı kriterlerinin mevcut olduğu belirlenmiştir. Psikiyatrik bir bozukluk saptanan 164 olgunun 147'sinde $(\% 89,6)$ travmanın bedensel etkileri "Basit Tıbbi Müdahale ile Giderilebilecek Ölçüde Hafif Nitelikte" olmasına rağmen travmanın ruhsal etkileri de göz önüne alındığında mevcut yaralanmalarının "Basit Tıbbi Müdahale ile Giderilebilecek Ölçüde Hafif Nitelikte Olmadığı” tespit edilmiştir. Cinsiyet ile olayın türü arasındaki ilişki incelendiğinde; darp eyleminin \%76,6'sının ( $\mathrm{n}=118)$ kadınlara karşı işlendiği $(\mathrm{p}<0,05)$ belirlenmiştir.

Sonuç: Bu çalışmada; ruhsal travmanın bulguları ortaya konulmuş ve adli raporun sonucuna etki ettiği belirlenmiştir. Adli makamlar tarafından gönderilen olgular ruhsal açıdan mutlaka değerlendirilmeli ve ruhsal travmanın bulguları adli raporlarda belirtilmelidir. Travma olgularında multidisipliner yaklaşım daha sağlıklı bir yargılama yürütülmesini sağlayacaktır.

Anahtar Kelimeler: Travma, Adli rapor, Psikiyatri, Konsültasyon
DOI: $10.17986 / \mathrm{blm} .1400$

Orhan Meral: MD. Spec. Dr., Çiğli

Training and Research Hospital,

Department of Forensic Medicine, İzmir

Eposta: orhanmeral@ymail.com

ORCID iD: https://orcid.org/0000-0002-

7159-1595

Nusret Ayaz: MD. Spec. Dr., Niğde

Training and Research Hospital,

Department of Forensic Medicine,

Niğde

Eposta: nusretayaz@gmail.com

ORCID iD: https://orcid.org/0000-0001-

9302-2820

Acknowledgement:

* Sorumlu Yazar / Corresponding

Author

Conflict of Interest

The authors declare that they have no

conflict of interests regarding content of this article.

Support Resources

The Authors report no financial support regarding content of this article.

\section{Ethical Statement}

Permission for the study was obtained from Bozyaka Training and Research

Hospital Clinical Research Ethics

Committee with the letter dated 9

October 2019 and issued 01, and the

Helsinki Declaration criteria were taken

into consideration.

This article is English version of the

manuscript entitled as "Psikiyatri

Konsültasyonlarının Adli Rapor

Düzenleme Sürecine Etkisi”

Geliş: 22.04 .2020

Düzeltme: 29.06 .2020

Kabul: 16.07 .2020 


\section{Introduction}

Forensic Medicine is the scientific branch that brings together the law and medicine as a multidisciplinary approach that investigates medical subjects related to the law. Points requested to be evaluated by the judicial authorities are examined with medical approaches and evaluated according to objective criteria (1).

In cases requiring expert, specific or technical knowledge, the judicial authorities may seek the opinions of experts (2). Opinions of physicians are also requested on health-related issues. The physician who is asked to prepare a forensic report is obliged to fulfil this duty as an expert (2). The majority of the reports prepared in forensic medicine practices in our country are forensic trauma reports evaluating the severity of trauma (3). These reports are prepared in line with the issues written in the articles under the heading of "Offences Against Physical Integrity" of the Turkish Criminal Code (TCC) and in a language that the judicial authorities can understand (4).

In 2005, a guide titled "Evaluation of Injury Crimes Defined in the Turkish Criminal Code From the Perspective of Forensic Medicine" was prepared in order to provide a nationwide standard while evaluating injury crimes from a forensic perspective. This guide was updated in 2013 and 2019, and it was emphasized that the physical effects of trauma as well as the mental effects of trauma should be taken into account in injury crimes (5).

Consultation, which is an integral part of today's medical practices, is requested from the relevant branch physician in case of a need for scientific knowledge in any area of specialization. The guideline used in forensic medicine practices also includes criteria for determining "mental health damage caused by trauma". It is essential to establish a relationship between psychological complaints and trauma. Therefore, a psychiatric evaluation should be performed in order to reflect the presence of mental influence onto the forensic report $(5,6)$.

Although the psychological effects of trauma are accepted as concrete evidence in our country, it has been reported that physical findings are more important in the opinions of both the investigation and judicial authorities and physicians (7). The aim of this study was to draw attention to the importance of the psychiatric consultation requested by the Forensic Medicine outpatient clinic to the cases exposed to different types of trauma, in revealing the presence and frequency of traumatic psychological effects as well as their impact on the forensic report.

\section{Materials and Methods}

\subsection{Data Collection}

This study is retrospective in nature. Among the cases sent to Bozyaka Training and Research Hospital Forensic Medicine outpatient clinic for a forensic report request between June 2016 and September 2019, 192 cases consulted to the Psychiatry Outpatient Clinic were included in the study. Psychiatric evaluation was performed by psychiatrists in accordance with DSM-5 (Diagnostic and Statistical Manual of Mental Disorders-5) (8).

In addition to the demographic characteristics of the cases such as age and gender, the authority requesting the forensic report, the type and date of the incident/crime, the date of examination at Forensic Medicine outpatient clinic and psychiatric consultation, and the results of the consultation were examined and the effect of the results on the forensic report was investigated.

\subsection{Statistical Analysis}

The data were analysed with the SPSS program (version 22.0). Demographic data are expressed as mean value \pm standard deviation and/or percentage. Fisher's exact test and Pearson's chi-square test were used in the analysis of the data determined by frequency, percentage and count. Comparison values were calculated at $95 \%$ confidence interval; $p$ values below 0.05 were considered statistically significant.

\section{Ethical Statement}

Permission for the study was obtained from Bozyaka Training and Research Hospital Clinical Research Ethics Committee with the letter dated 9 October 2019 and issued 01, and the Helsinki Declaration criteria were taken into consideration.

\section{Results}

Of the 192 cases included in the study 54 (28.1\%) were male and $138(71.9 \%)$ were female. Their age ranged between 18 and 80 . The mean age was $39.44 \pm 13.84$. When the distribution of the cases according to age groups was examined, it was found that the most cases were between the ages of 18-30 $(n=60,31.3 \%)$, and the most frequently applied was in $2017(\mathrm{n}=63,32.8 \%) .90 .7 \%$ $(n=174)$ of the judicial authorities requesting forensic reports were district police headquarters; when the types of crimes were examined, it was revealed that majority of forensic reports were requested due to the crime of deliberate injury with a rate of $85.9 \%(n=165)$ and $80.2 \%$ $(n=154)$ of the cases were injured as a result of assault. The demographic data of the cases and incidents are as shown in Table 1. 


\begin{tabular}{|l|l|}
\hline Table 1. Demographics & $\mathrm{n}(\%)$ \\
\hline Gender & $54(28.1)$ \\
Male & $138(71.9)$ \\
\hline Female & $18-80$ \\
\hline Aged between & $39.44 \pm 13.84$ \\
\hline Mean age & $41.91 \pm 13.63$ \\
Male & $38.48 \pm 13.85$ \\
Female & \\
\hline Age groups & $60(31.3)$ \\
18-30 & $45(23.4)$ \\
$31-40$ & $43(22.4)$ \\
41-50 & $27(14.1)$ \\
$51-60$ & $17(8.8)$ \\
61 and above & \\
\hline Number of reports by year & $36(18.8)$ \\
2016 & $63(32.8)$ \\
2017 & $47(24.4)$ \\
2018 & $46(24.0)$ \\
\hline 2019 & \\
\hline Requested by & $174(90.7)$ \\
Police headquarters & $7(3.6)$ \\
Gendarmerie station command & $7(3.6)$ \\
Public prosecutor's office & $4(2.1)$ \\
Court & $165(85.9)$ \\
\hline Type of crime & $27(14.1)$ \\
\hline Deliberate injury & $154(80.2)$ \\
Reckless (accidental) injury & $13(6.8)$ \\
\hline Type of incident & $10(5.2)$ \\
Physical assault & $8(4.2)$ \\
Traffic accident outside the vehicle & $3(1.6)$ \\
Traffic accident inside the vehicle & $2(1.0)$ \\
Penetrating injury & $1(0.5)$ \\
Firearms injury & \\
Fall from height & \\
Electric shock & \\
Burn injury & \\
\hline
\end{tabular}

It was found that a total of $158(82.3 \%)$ patients, 92 $(47.9 \%)$ in the first three days, applied to the forensic medicine outpatient clinic within the first month after the incident, and all of these patients were consulted to the psychiatry department within the first month following the incident. (Table 2).

In the medical histories of the cases, there was no information about whether they had previously been diagnosed with any mental disorder or not. As a result of the psychiatry consultation, no psychiatric effect was determined in $28(14.6 \%)$ cases, and $164(85.4 \%)$ cases were found to meet the diagnostic criteria of a psychiatric disorder according to DSM-5 (Table 3). In forensic reports prepared as a result of forensic medical evaluation made in line with this information; It was observed that the injuries of 28 patients without a mental disorder were "of a nature which can be eliminated with a simple medical intervention", and that the injuries of 164 patients with any psychiatric disorder were "of a nature which cannot be eliminated with a simple medical intervention".

\begin{tabular}{|c|c|c|}
\hline $\begin{array}{l}\text { Time from the incident to presentation at } \\
\text { Forensic Medicine outpatient clinic }\end{array}$ & $\mathbf{n}$ & $\%$ \\
\hline Within the first 3 days & 92 & 47.9 \\
\hline 4 - 30 days & 66 & 34.4 \\
\hline 1 - 6 months & 22 & 11.5 \\
\hline More than 6 months & 12 & 6.2 \\
\hline $\begin{array}{l}\text { Time from the incident to Psychiatry } \\
\text { consultation }\end{array}$ & $\mathbf{n}$ & $\%$ \\
\hline 4 - 30 days & 158 & 82.3 \\
\hline $1-6$ months & 22 & 11.5 \\
\hline More than 6 months & 12 & 6.2 \\
\hline
\end{tabular}

Table 3. Mental health findings determined as a result of psychiatric consultation

\begin{tabular}{|l|l|l|}
\hline & $\mathrm{n}$ & $\%$ \\
\hline Acute Stress Disorder & 114 & 59.4 \\
\hline No mental health disorder & 28 & 14.6 \\
\hline Adjustment Disorder & 25 & 13.0 \\
\hline Post-Traumatic Stress Disorder & 21 & 10.9 \\
\hline Permanent Organic Mental Disorder & 4 & 2.1 \\
\hline
\end{tabular}

In $147(89.6 \%)$ of the patients with mental disorders, although the physical effects of trauma were found to be "of a nature which can be eliminated with a simple medical intervention", when the mental effects were considered, the current injury was then determined to be "of $a$ nature which cannot be eliminated with a simple medical intervention". In 17 (10.4\%) cases, the physical effects of the injuries were "of a nature which cannot be eliminated with a simple medical intervention" due to the findings of bone fracture and / or life-threatening trauma and therefore, the psychiatric disorder determined according to the DSM-5 did not change the result of the forensic report (Table 4). 
Table 4. The effect of the mental health findings determined as a result of consultation on the forensic report

\begin{tabular}{|l|l|l|l|}
\hline & $\begin{array}{l}\text { Changed to “of a nature which cannot } \\
\text { be eliminated with a simple medical } \\
\text { intervention" }\end{array}$ & $\begin{array}{l}\text { No changes occurred } \\
*\end{array}$ & Total \\
\hline & $\mathbf{n}(\mathbf{\%})$ & $\mathbf{n}(\%)$ & $\mathbf{n}$ \\
\hline Acute Stress Disorder & $106(93.0)$ & $8(7.0)$ & 114 \\
\hline Adjustment Disorder & $24(96.0)$ & $1(4.0)$ & 25 \\
\hline Post-Traumatic Stress Disorder & $17(81.0)$ & $4(19.0)$ & 21 \\
\hline $\begin{array}{l}\text { Permanent Organic Mental } \\
\text { Disorder }\end{array}$ & 0 & $4(100.0)$ & 4 \\
\hline $\begin{array}{l}\text { Total } \\
\text { * Physical injuries were already considered as “of a nature which cannot be eliminated with a simple medical intervention", therefore the } \\
\text { conclusion did not change when the mental health findings were considered as well. }\end{array}$ & $\mathbf{1 7}$ \\
\hline
\end{tabular}

Although there is no data on the gender of the person who committed the act in medical records, $75.8 \%$ (n $=125)$ of the crimes of intentional injury were commit- ted against women $(\mathrm{p}<0.05)$, and $76.6 \%(\mathrm{n}=118)$ of the crimes of assault were also committed against women $(\mathrm{p}<0.05)$ (Table 5).

\begin{tabular}{|c|c|c|c|c|c|c|c|c|c|c|}
\hline \multirow[t]{2}{*}{ Gender } & \multicolumn{3}{|c|}{ Deliberate Injury } & \multirow[t]{2}{*}{ Total } & \multicolumn{5}{|c|}{ Reckless Injury } & \multirow[t]{2}{*}{ Total } \\
\hline & $\begin{array}{l}\text { Physical } \\
\text { assault }\end{array}$ & $\begin{array}{l}\text { Penetrating } \\
\text { Injury }\end{array}$ & $\begin{array}{l}\text { Firearm } \\
\text { Injury }\end{array}$ & & TAIV & TAOV & FFH & $\begin{array}{l}\text { Electric } \\
\text { Shock }\end{array}$ & $\begin{array}{l}\text { Burn } \\
\text { injury }\end{array}$ & \\
\hline \multirow[t]{2}{*}{ Male } & 36 & 3 & 1 & 40 & 2 & 8 & 2 & 1 & 1 & 14 \\
\hline & $23.4 \%$ & $37.5 \%$ & $33.3 \%$ & $24.2 \%$ & $14.3 \%$ & $57.2 \%$ & $14.3 \%$ & $7.1 \%$ & $7.1 \%$ & $51.9 \%$ \\
\hline \multirow[t]{2}{*}{ Female } & 118 & 5 & 2 & 125 & 8 & 5 & 0 & 0 & 0 & 13 \\
\hline & $76.6 \%$ & $62.5 \%$ & $66.7 \%$ & $75.8 \%$ & $61.5 \%$ & $38.5 \%$ & $0.0 \%$ & $0.0 \%$ & $0.0 \%$ & $48.1 \%$ \\
\hline \multirow[t]{2}{*}{ Total } & 154 & 8 & 3 & 165 & 10 & 13 & 2 & 1 & 1 & 27 \\
\hline & $100.0 \%$ & $100.0 \%$ & $100.0 \%$ & $100.0 \%$ & $100.0 \%$ & $100.0 \%$ & $100.0 \%$ & $100.0 \%$ & $100.0 \%$ & $100.0 \%$ \\
\hline
\end{tabular}

TAIV: Traffic accident inside the vehicle, TAOV: Traffic accident outside the vehicle, FFH: Fall from height.

When the relationship between the age group and the type of the incident and the nature (deliberate or reckless) of the incident causing injury was examined separately, no statistically significant difference was found, also no statistically significant correlation was found between the effect of the requested consultations on forensic medical evaluation and the age group, gender of the cases, the type of the incident, deliberate or reckless nature of the incident, the time from the incident to the request for consultation. ( $p>0.05)$.

\section{Discussion}

Psychiatry is reported to be the most frequently requested consultation in forensic medicine practices (6). In this study, 192 cases were consulted to the Psychiatry Department among the cases sent to the Forensic Medicine outpatient clinic of Bozyaka Training and Research Hospital between June 2016 and September 2019. The majority of the cases are women and are in the 18-30 age group and the mean age is $39.44 \pm 13.84$. Also most frequently; It was determined that the cases were sent by the district police headquarters, the crime of deliberate injury was committed, and the cases were injured as a result of an assault. The number of studies similar to this study is very limited in our country. In a study by Can et al. (7) where $56.3 \%$ of the cases were women, the average age was found to be $40.30 \pm 17.17$, the most frequent injuries were the result of traffic accidents $(29.6 \%)$ and blunt trauma due to interpersonal violence $(28.9 \%)$.

When the definition "injury that inflicts pain on someone else's body / causes deterioration of their health or perception" by TCC is examined; it can be understood that the physical and psychological findings related to trauma are piled under the same title and it is aimed to determine the severity of these injuries. Therefore, the psychological effects of trauma should be investigated as 
well as the physical effects $(5,9)$. In this study, it is seen that $82.3 \%$ of the cases applied to the Forensic Medicine outpatient clinic within the first month after the incident and all of these cases were consulted to the psychiatry department within the first month after the incident. Since psychological effects mostly wear off over time, in the case of mental complaints in forensic cases, performing a psychiatric examination at the earliest possible period is of great importance in terms of revealing the psychological effects and establishing the causal relationship between the trauma and these findings. Those who suffer from a crime require a forensic psychiatric examination and a report (10).

Psychiatrists most frequently follow the DSM-5 Diagnostic Criteria Reference Manual published by the American Psychiatric Association in 2013 when evaluating the impact of trauma related to mental disorders that develop due to the trauma (8). They then assess whether the findings detected as a result of the psychiatric examination meet the criteria of one of the diagnoses in the "Trauma and Stressor-related Disorders" section of the DSM-5 handbook (Table 6). In this assessment, the decision is made by evaluating factors such as the severity of the trauma, the duration of the findings, the clinical condition and functionality of the patient, and the causality of the trauma (cause-effect relationship between the incident and the findings) (5).

Table 6. Trauma and Stressor-related Disorders

Reactive Attachment Disorder

Disinhibited Social Engagement Disorder

Post-Traumatic Stress Disorder

Acute Stress Disorder

Adjustment Disorders

Other Specified Trauma and Stressor-Related Disorder

Unspecified Trauma and Stressor-Related Disorder

Psychiatry physicians sometimes are concerned about forensic issues, and forensic issues take up little space in general psychiatry training. However every psychiatrist should have a general knowledge of this issue, so that both psychiatrists can be protected from judicial or administrative damages, and the patients they treat will not be at risk for loss of their rights (11). In a study involving 1084 patients admitted to the hospital due to trauma, a psychiatric disorder was found in $31 \%$ of them at the end of 12 months, and $22 \%$ of those reported a psychiatric disorder that they had never experienced before (12). Depression, generalized anxiety disorder and posttraumatic stress disorder were the most common in these patients (12). In another study, it was stated that at least one psychiatric disorder developed in $28 \%$ of the patients
72 months after a serious injury and it posed an increased risk for incapacity to work (13). In this study, it was determined that $85.4 \%$ of the cases who were consulted to the Psychiatry Outpatient Clinic met the diagnostic criteria for a mental disorder according to DSM-5. Acute stress disorder has been reported the most. In the study of Can et al., this rate was found to be $81 \%$ (7). Considering the contribution of revealing mental impairments to both the treatment process and forensic medical evaluation, we recommend that patients who describe mental complaints and / or who are thought to have mental impairment in the Forensic Medicine outpatient clinic should be referred for psychiatric consultation.

Mental health effects are important in determining whether an injury is "of a nature which can/cannot be eliminated with a simple medical intervention". If the person is determined to have a disorder in accordance with DSM-5 as a result of this trauma, the forensic report states that the injury is of a "of a nature which cannot be eliminated with a simple medical intervention". In this study, it was determined that $85.4 \%$ of the patients who requested psychiatric consultation were diagnosed with a psychiatric disorder according to DSM-5, and in $89.6 \%$ of these cases although the physical findings of the trauma were "of a nature which can be eliminated with a simple medical intervention"; when the psychological effects of the trauma were considered, current injuries were determined to be "of a nature which cannot be eliminated with a simple medical intervention". In this case, the result of the forensic report has changed and the effect of the trauma has gained a more severe character. Consequently, the course of the trial will be affected and the sentence will become more serious. In order not to create new grievances, it is crucial that the relationship between psychological findings and trauma is established in a scientific/evidence-based manner, and it is thought that a multidisciplinary approach in the arrangement of these reports may prevent possible medical practice errors.

\section{Conclusion}

This study is one of the rare studies on this subject in our country. In Forensic Medicine practice, the physical effects of trauma as well as the mental effects are of importance while evaluating Offences Against Physical Integrity (TCC articles $86,87,88$, and 89 ) due the definitions such as "causing the deterioration of perception ability", "causing the function of one of his senses or organs to be constantly weakened or lost", "whether the effect of the act on the person is of a nature which can or cannot be eliminated with a simple medical intervention" (5).

The findings obtained are important in terms of emphasizing the importance of the existence and frequency 
of the psychological effects of trauma in traumatized cases and its effect on the forensic report. A systematic and multidisciplinary approach should be adopted in forensic cases. Psychiatry consultation should be sought in case of mental complaints and / or findings, as well as consultations to other clinical branches related to physical trauma. In addition, in such cases; establishing multidisciplinary teams and obtaining medical data about their medical history and whether they have any previous mental disorders will provide a healthier assessment. Establishing psychological trauma is important not only for the health of the individual, but also for the protection of legal rights and a healthy judicial process.

\section{Limitations}

The absence of children under 18 years of age due to the lack of a Child and Adolescent Mental Health and Diseases department at Bozyaka Training and Research Hospital, where the study was conducted as well as cases who were recommended to follow-up as a result of consultation but did not follow the recommendation and did not apply again, constitutes the limitations of the study. Another limitation of the study is that there is no data on whether there is any mental disorder in the medical history of the patients.

\section{Acknowledgement}

We would like to thank Bozyaka Training and Research Hospital Psychiatry Service physicians and other employees for facilitating the collection of study data.

\section{References}

1. Dokgöz H, Koçak U. Adli Bilimler. İçinde: Dokgöz H Editör, Adli Tıp \& Adli Bilimler. Ankara: Akademisyen Kitabevi; 2019. s. 1-30.

2. Dokgöz H. Bilirkişilik. İçinde: Dokgöz H Editör, Adli Tıp \& Adli Bilimler. Ankara: Akademisyen Kitabevi; 2019. s. $31-50$.
3. Akbaba M, Isır AB, Karaarslan B, Dülger HE. Gaziantep Üniversitesi Adli Tıp Anabilim Dalında Düzenlenmiş Adli Raporların Değerlendirilmesi (2005-2011). Bull Leg Med. 2012;17(2):10-18. https://doi.org/10.17986/ blm.201217226.

4. Kar H, Dokgöz H. Adli Rapor. İçinde: Dokgöz H Editör, Adli Tıp \& Adli Bilimler. Ankara: Akademisyen Kitabevi; 2019. s. 359-378.

5. Balcı Y, Çolak B, Gürpınar K, Anolay NN. Türk Ceza Kanunu'nda Tanımlanan Yaralama Suçlarının Adli Tıp Açısından Değerlendirilmesi Rehberi, 2019.

6. Şener MT, Kök AN. Consultation in The Practice of Forensic Medicine. Bull Leg Med. 2011;16(3):77-80. https://doi. org/10.17986/blm.2011163729

7. Can İÖ, Uyanıker ZD, Ulaş H, Karabağ G, Cimilli C, Salaçin S. Mental Findings in Trauma Victims. Nöropsikiyatri Arşivi. 2013; 50: 230-236.

8. American Psychiatric Association. Diagnostic and Statistical Manual Of Mental Disorders (DSM-5®). Washington, D.C: American Psychiatric Pub; 2013.

9. Karakaya I, Çolak B. Posttraumatic Stres Disorder in Children and Adolescents and Evaluation in Forensic Medicine. Bull Leg Med. 2007;12(2):82-87. https://doi. org/10.17986/blm.2007122642.

10. Öncü F, Sercan M. Ceza Hukukunda Adli Psikiyatri. Sercan M editör, Adli Psikiyatri Uygulama Kılavuzu, 1. Bask1, Ankara, Türk Psikiyatri Derneği Yayınları; 2007. s. 33-50.

11. Saygilı Ç, Ak S, Cantürk G. What Is The Level of Forensic Psychiatry Knowledge Among Psychiatrists in Turkey? "In Your Opinion, Should Forensic Psychiatry Be a Subspecialty?” Bull Leg Med. 2019; 24 (1):1-8. https://doi. org/10.17986/blm.2019149810.

12. Bryant RA, O'donnell ML, Creamer M, McFarlane AC, Clark CR, Silove D. The psychiatric sequelae of traumatic injury. Am J Psychiatry. 2010;167:312-20. https://doi. org/10.1176/appi.ajp.2009.09050617.

13. O'Donnell ML, Alkemade N, Creamer MC, et al. The long-term psychiatric sequelae of severe injury: a 6-year follow-up study. J Clin Psychiatry. 2016;77(4):e473-e479. doi:10.4088/JCP.14m09721. 